$12-1-2013$

\title{
Preoperative spinal tumor embolization: an institutional experience with Onyx.
}

\author{
George M. Ghobrial, MD \\ Thomas Jefferson University \\ Nohra El-Chalouhi, MD \\ Thomas Jefferson University \\ James Harrop, MD \\ Rothman Institute, Thomas Jefferson University \\ Richard Dalyai, MD \\ Thomas Jefferson University
}

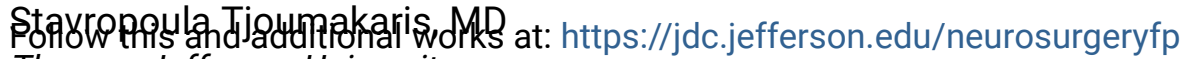
Thomas Jefferson University

Part of the Medicine and Health Sciences Commons

\section{Let us know how access to this document benefits you}

\section{Recommended Citation}

Ghobrial, MD, George M.; El-Chalouhi, MD, Nohra; Harrop, MD, James; Dalyai, MD, Richard; Tjoumakaris, MD, Stavropoula; Gonzalez, MD, L Fernando; Hasan, MD, David; Rosenwasser, MD, Robert; and Jabbour, MD, Pascal, "Preoperative spinal tumor embolization: an institutional experience with Onyx." (2013). Department of Neurosurgery Faculty Papers. Paper 53. https://jdc.jefferson.edu/neurosurgeryfp/53

This Article is brought to you for free and open access by the Jefferson Digital Commons. The Jefferson Digital Commons is a service of Thomas Jefferson University's Center for Teaching and Learning (CTL). The Commons is a showcase for Jefferson books and journals, peer-reviewed scholarly publications, unique historical collections from the University archives, and teaching tools. The Jefferson Digital Commons allows researchers and interested readers anywhere in the world to learn about and keep up to date with Jefferson scholarship. This article has been accepted for inclusion in Department of Neurosurgery Faculty Papers by an authorized administrator of the Jefferson Digital Commons. For more information, please contact: JeffersonDigitalCommons@jefferson.edu. 


\section{Authors}

George M. Ghobrial, MD; Nohra El-Chalouhi, MD; James Harrop, MD; Richard Dalyai, MD; Stavropoula Tjoumakaris, MD; L Fernando Gonzalez, MD; David Hasan, MD; Robert Rosenwasser, MD; and Pascal Jabbour, MD 


\section{As submitted to:}

Clinical neurology and neurosurgery.

Preoperative Spinal Tumor Embolization: An Institutional

Experience with Onyx

And later published as:

Volume 115, Issue 12, December 2013, pages: 2457-2463.

DOI: 10.1016/j.clineuro.2013.09.033

George M. Ghobrial MD, ${ }^{1}$ Nohra Chalouhi MD, ${ }^{1}$ James Harrop MD, ${ }^{1}$ Richard T Dalyai MD, ${ }^{1}$ StavropoulaTjoumakaris , L. Fernando Gonzalez MD, ${ }^{1}$ David Hasan MD, ${ }^{2}$ Robert H. Rosenwasser MD, ${ }^{1}$ Pascal Jabbour MD ${ }^{1,2}$

1- Department of Neurosurgery, Thomas Jefferson University and Jefferson Hospital for Neuroscience, Philadelphia, Pennsylvania, USA

2- Department of Neurosurgery, University of Iowa .

3 Corresponding author:

Pascal M. Jabbour, MD

Assistant Professor

Department of Neurological Surgery 
Division of Neurovascular Surgery and

Endovascular Neurosurgery

Thomas Jefferson University Hospital

909 Walnut street 2nd Floor

Philadelphia PA 19107

\title{
$\mathrm{T}: \underline{2159557000}$
}

\section{F:2155037038}

Email: pascal.jabbour@jefferson.edu

\begin{abstract}
BACKGROUND: Preoperative embolization has the potential to decrease intraoperative blood loss and facilitate spinal cord decompression and tumor resection . OBJECTIVE: We report our institutional experience with the embolization of hypervascular extradural spinal tumors with Onyx as well as earlier embolic agents in a series of 28 patients. METHODS: A retrospective case review was conducted on patients undergoing preoperative transarterial embolization of a spinal tumor between 1995 and 2012 at our institution. RESULTS: 28 patients met the inclusion criteria, with a mean age of 60.6 years. Twenty-eight patients had metastatic tumors. In 14 $(50 \%)$ patients the metastases were from renal cell carcinomas. 54 vessels were embolized using PVA, NBCA, Onyx, coils, or embospheres. Sixteen patients were treated with Onyx, 6 patients with PVA, 3 patients with embospheres, 2 patients with NBCA, and 3 patients with a combination of embolic agents. The average decrease in tumor blush was $97.8 \%$ with Onyx versus $92.7 \%$ with the rest of the embolic agents $(\mathrm{p}=0.08)$. The estimated blood loss was 1616 $\mathrm{ml}$ (range 350-5000 ml). Blood loss was $750 \mathrm{cc}$ on average with Onyx versus 1844 with the rest of the embolic agents $(\mathrm{p}=0.14)$. The mean length of stay was 16 days. The mortality rate was zero. Pre- and post-operative modified Rankin Score $(\mathrm{mRS})$ did not differ significantly in the series (3.12 vs. 3.10, respectively, $\mathrm{p}=0.9$ ). CONCLUSION: In our experience, the use of transarterial tumor embolization as an adjunct for spinal surgery is a safe and feasible option.
\end{abstract}




\section{Introduction}

It is estimated that as many as $10 \%$ of cancer patients develop spinal metastases during the course of their disease.[1] The goal of surgical treatment of symptomatic metastatic lesions is to improve the quality of life, preserve neurological function, achieve mechanical spinal stability, and in some cases provide diagnostic tissue for further treatment. Surgery in patients with hypervascular spinal tumors (primary or metastatic) can be complicated by significant intraoperative bleeding. Preoperative embolization has the potential to decrease intraoperative blood loss and facilitate spinal cord decompression and tumor resection.[2-10] A variety of liquid embolic agents have been utilized for presurgical tumor embolization, most frequently polyvinyl alcohol (PVA). More recently, Onyx has emerged as a highly efficient agent for treatment of intracranial and spinal arteriovenous malformations and fistulas.[11] Its use for embolization of spinal tumors, however, has been very limited. In this study, we report our institutional experience with the embolization of hypervascular extradural spinal tumors with several embolic agents in a series of 28 patients. We highlight the safe and effective use of Onyx for spinal tumor embolization.

\section{Methods}

Institutional review board approval was obtained prior to data collection. A retrospective case review was conducted on consecutive patients who underwent preoperative transarterial embolization of a spinal tumor between 1995 and 2012 at our institution. Patients with intradural tumors were excluded from the study. Patients were selected for pre-operative embolization based on preoperative consensus of the senior spine surgeons for findings considered high-risk for intraoperative hemorrhage: known tumor histology (renal cell carcinoma, thyroid, melanoma) or pre-operative MRI findings of hypervascularity (flow voids, bright contrast enhancement, intratumoral hemorrhage). Aggressive hemangiomas treated operatively for neurological deficits were also included given the high risk for catastrophic intraoperative blood loss. All of the hypervascular tumors defined above were then evaluated angiogaphically for further diagnostic purposes or, potential embolization.

Angiographic Technique 
All procedures were performed through the transfemoral route under general anesthesia and somatosensory evoked monitoring. Patients were heparinized and activated clotting time was maintained at 2 times the patient's baseline intraoperatively. The angiographic technique has been described previously.[12] A 6 French groin sheath is introduced into the femoral artery, followed by a $\mathrm{H} 1 \mathrm{H}$ spinal catheter or a Cobra 2 catheter (Cordis Corp. Bridgewater, NJ). Aortography is undertaken and selective bilateral catheterization of the corresponding segmental arteries (including 2 levels above and below the lesion) is performed. Spinal cord supply, tumor feeding pedicles, and the presence of normal en passage vessels are carefully evaluated. Depending on the conformation and origin of the feeder artery, various preshaped $5 \mathrm{~F}$ catheters are selected for superselective catheterization including SL10 (Boston Scientific, Natick, MA), echelon 10 (EV3, Plymouth, MN) and marathon EV3 (EV3, Plymouth, MN).

\section{Embolization Technique}

Through a superselectively introduced microcatheter, a direct infusion of polyvinyl alcohol (PVA), n-butyl cyanoacrylate (NBCA), embospheres, or Onyx was performed into the branch supplying the tumor. Flow control techniques were often utilized with PVA to make particles flow preferentially into the feeding branches of the tumors, rather than normal tissue. A repeat angiogram was obtained immediately after embolization in all cases to verify the changes in tumor blood flow.

Multiple formulations of Onyx are available in the United States for clinical use. In this study, the low-viscosity agent, Onyx 18, was utilized for most spinal embolizations as it allows for better penetration of the tumor vasculature. Onyx-18 is composed of $6 \%$ ethylene vinyl alcohol copolymer and 94\% DMSO.[13] The feeding artery was superselectively catheterized with an Echelon 10 (EV3 Endovascular, inc., Plymouth, MN) microcatheter or Marathon Catheter, as stated above. The microcatheter was then flushed with normal saline, followed by dimethylsulfoxide (DMSO). Next, Onyx was injected until adequate penetration of the tumor was achieved (Figure 1). A percent obliteration of the tumor blush was obtained from each operative report dictated, as well as preoperative and postoperative percent change of angiographic nidus blush. 
Spinal Surgery

Surgical interventions in all cases were performed within twenty four hours, typically, on the day following the embolization. The goals of surgery were spinal cord decompression, tissue diagnosis, and restoration of spinal alignment and stability. This was performed most commonly through the posterior approach, or alternatively through anterior or combined anterior-posterior approaches. Intra-operative blood loss was estimated by the anesthesiologist.

\section{Complications}

Procedural complications were defined as an adverse event prolonging hospital stay, or readmission within sixty days for a reason felt by the senior authors to be attributed to procedural technique. This data was collected via a retrospective analysis of electronic medical records and were defined as retroperitoneal hematoma, femoral arterial pseudoaneurysm, stroke, myocardial infarction, pulmonary embolism, ileus, arterial dissection, and bleeding at the site of puncture. Additionally, all other complications not attributed to endovascular embolization, such as those due to the morbidity of metastatic disease and decompression spinal fusion surgery were recorded, as well as the hospital length of stay.

Intraoperative blood loss was pulled from anesthesiologist records. Final pathologist reports were pulled from electronic records. Data on contrast usage, type and volume of embolization material, the number of embolized segmental vessels were recorded from intraoperative surgeon reports. Lastly, the percent obliteration as estimated by decrease in the tumor blush as observed by the endovascular neurosurgeon was reported from operative notes.

Specific patient data mentioned above on the use of Onyx embolysate was then compared directly to patients who had been treated with earlier embolization materials.

\section{Follow-up}

Patient follow-up data was evaluated from electronic medical records. The most recent follow-up visit within ninety days of admission was evaluated for neurologic improvement and functional status.

Statistical Analysis 
Statistical analysis was undertaken for the treatment groups via a software package (JMP statistical software, edition 9, www.jmp.com) with a Wilcoxon Rank Sum Test. Statistical significance was defined as a $\mathrm{P}$ value of $<0.05$.

\section{Results}

There were thirty consecutive embolization patients who had met the criteria for the study, and all thirty were included (Table 1). There were 14 women and 14 men with a mean age of 60.8 years. Twenty-eight patients had metastatic tumors. In 14 (50\%) patients the metastases were from renal cell carcinomas. Table One illustrates the baseline characteristics of the patient population. A total of 54 vessels were embolized using PVA, NBCA, Onyx, coils, or embospheres. Sixteen patients were treated with Onyx, 6 patients with PVA, 3 patients with embospheres, 2 patients with NBCA, and 3 patients with a combination of embolic agents. The mean volume of iodinated contrast used during the procedure was 164 milliliters $(\mathrm{mL})$. The number of vessels embolized per patient was 1.8 on average. The total volume of Onyx used was $1.86 \mathrm{ml}$ on average(Table 2). There were no periprocedural complications related to contrast administration or transarterial embolization. Notably, There were two wound washouts during the same hospital stay, one revision of instrumentation, three thromboembolic events which were diagnosed during the postoperative course, and one post-op ileus (Table 3a). Data on the average number of levels instrumented, presence of decompression, corpectomy, or circumferential fusion were recorded (Table 3b). The mortality rate was zero. Post embolization, the average tumor blush decrease as reported by the interventionalist was $95 \%$, where available. Specifically, the average decrease in tumor blush was $97.8 \%$ with Onyx versus $92.7 \%$ with the rest of the embolic agents $(p=0.08)$.

After embolization, the spinal surgery estimated blood loss(EBL) was $1616 \mathrm{ml}$, (range 350-5000 ml) although data on EBL was available for 16 of 28 patients (Table 3) The median length of stay was 16 days, and the median pre-operative and post-operative modified Rankin Score $(\mathrm{mRS})$ was 3.13 and 3.10 , respectively $(\mathrm{P}=0.9)$. 
Specifically, blood loss was $750 \mathrm{cc}$ on average using Onyx embolysate versus 1844 with the older embolic agents $(\mathrm{p}=0.14)$. Also, the decrease in tumor blush, hospital length of stay, and post-operative mRS were not significantly different (Table 4).

\section{Discussion}

With an expanding role for surgical excision of spinal metastases and other aggressive pathologies, adjunctive measures are increasingly used to improve both the effectiveness and safety of the usually palliative procedure. Around $60 \%$ of all spinal metastasis, $40 \%$ of benign spinal neoplasms, and 85\% of malignant spinal lesions are reportedly hypervascular.[5] Endovascular embolization prior to surgical excision of these hypervascular lesions may help identify regional vascular supply of the spinal cord, decrease intraoperative blood loss, decrease local recurrence, and even provide palliative pain relief. Hypervascular lesions can be encased by the regional arterial supply making surgical excision extremely difficult and risky without embolization. Hypervascular lesions most often embolized are renal cell carcinomas, germ cell tumors, and thyroid carcinomas.[14] At our center, consideration is given to preoperative embolization primarily for those spinal tumors that demonstrate avid enhancement on MR imaging or for patients who have a positive history of renal cell carcinoma. In our study, we sought assess the role of presurgical embolization for the main purpose of reducing intraoperative blood loss to improve surgical outcomes. The safety and efficacy of different embolic agents are also compared, though the small number of patients precludes definitive conclusions in this regard. This is to our knowledge the largest experience to date with an Onyx comparison to earlier generations of embolic materials in adults for preoperative embolization of spinal tumors.

We demonstrate in a series of thirty patients that endovascular preoperative embolization of extradural spinal tumors can be safely undertaken. The morbidity attributed to embolization in our series was zero, which correlates with the low rate of technical complications reported in prior retrospective studies (Table 5). There were three thromboembolic events which occurred after spinal surgery, greater than 48 hours after spinal embolization, and therefore were attributed 
to the combined risk factors of spinal surgery and malignancy. Nevertheless, complications may occur and include death, permanent neurologic deficits, arterial occlusions, and ischemia of surrounding tissues. Prabhu et al found that $8.5 \%$ of patients experience complications related to embolization of renal cell carcinomas.[15] Likewise, Vetter et al reported 2 postoperative brain stem infarctions in a series of 38 cervical spine embolizations.[10] The risk of contrast nephropathy should also be considered in patients with renal cell carcinoma, and every effort should be made to minimize the volume of contrast injected in this group of patients.

The results of this study demonstrate that Onyx embolization of spinal tumors is safe and effective. Furthermore, Onyx was associated with higher rates of angiographic obliteration and reduced intra-operative bleeding compared with other embolic agents, although the difference did not reach statistical significance. One obstacle to comparing intra-operative blood loss was the variability in surgeon experience, levels operated, and the volume of tumor that was resected by the surgeon. Also, there is no way to compare the degree of hypervascularity on imaging and the actual interaoperative bleeding risk.

The improved efficacy of embolization may be related to the inherent properties of Onyx that allow longer, slower, and more controlled injections with better penetration of the tumor vasculature. Also, Onyx has excellent surgical handling properties due to its black color, which facilitates manipulation and cauterization of blood vessels. In all patients who underwent Onyx embolization, there were no pulmonary embolisms, nor were there any post-operative events of neurologic decline to suggest distal Onyx migration.

A growing body of evidence supports the hypothesis that preoperative embolization may decrease intra-operative blood loss.[16, 17] In a series of 20 vertebral tumors preoperatively embolized by Guzman et al[17], a trend toward decreased blood loss and intraoperative time was demonstrated. Kato et al[18], found the blood loss to be almost half (1128 $\mathrm{ml}$ to $520 \mathrm{ml})$ with the addition of preoperative embolization (with either coils, NBCA, or PVA) for thoracic metastatic epidural tumors in 20 patients. Notably, percent embolization and time to surgery after devascularization were not significant factors affecting blood loss. Taniguchi et al evaluated the effects of preoperative embolization on total en bloc spondylectomy for solitary spinal metastases and found that intraoperative blood loss as well as the amount of blood transfused were significantly lower after preoperative embolization. [19] In another study, 
Manke et al[4] found blood loss to be $1.2 \mathrm{~L}$ in patients treated with preoperative embolization compared to $5 \mathrm{~L}$ in non-embolized patients.

More recently, Ashour and colleagues[20] demonstrate the safe and effective use of Onyx in the pediatric population, embolizing 21 spinal lesions of tumor and vascular etiology. Elhamaddy et al[21] also has expanded the technique of head and neck tumor treatment by demonstrating that direct tumor puncture with onyx preoperatively with a mean tumor devascularization of $87 \%$.

A limitation of this study is the lack of a control group that did not undergo presurgical embolization. Given the high risk of catastrophic blood loss from hypervascular tumors, a true control group with similar histologies would be difficult to obtain for this cohort. Given the high risk of catastrophic blood loss from these lesions, there are no matched controls to provide a comparison of the blood loss. Furthermore, given the relatively small population of patients undergoing embolization, subgroup analysis is difficult. A trend towards lower blood loss was noted with the Onyx group, but does not account for the high variability in the levels fused, circumferential decompression, extent of angiographic obliteration, and perioperative hypervascularity on imaging (Table 3b). One additional consideration regarding blood loss is the lack of data available for half of the study population. This variability, as well as the broad range of tumor pathologies should be kept in mind when drawing conclusions about the efficacy in reducing intraoperative blood loss.

Regardless of the technique, however, presurgical embolization appears to have an excellent safety profile. While a number of aforementioned papers demonstrate the safety and benefit of decreased intraoperative blood loss with the use of preoperative embolization, a recently published univariate analysis of sixty-two patients with prior preoperative embolization and tumor resection did not find tumor vascularity as a significant factor affecting blood loss.[22] Kobayashi and colleagues found the tumor volume, the invasiveness of the planned procedure, as well as the approach to be significant factors. Multivariate analysis only showed the extent of the surgical procedure to be the only significant factor, while tumor characteristics such as the vascularity, histology, and particulars of embolization to be not statistically significant.[22] Robial and colleagues, in a retrospective review of microsphere preoperative 
embolization for metastatic tumor, found no difference in blood loss regardless of embolization. Instead, the deciding factor was the extent of the procedure, specifically, whether or not a vertebrectomy was performed.[23] Elhammady et al[24] followed forty-three patients embolized with Onyx alone, fourteen of which underwent a direct tumor puncture and embolization. They conclude that direct tumor puncture might be the best way to penetrate the blood-barrier in order to limit blood loss. Given the variability in the pathologies, as well as the method of delivery of Onyx, little can be inferred regarding the transarterial route alone as well as the effectiveness for spinal pathologies. Still, these findings are intriguing given the growing body of evidence in support of decreasing blood loss, and warrant further investigation with randomized controlled studies.

\section{Conclusion}

In our experience, the use of transarterial tumor embolization with Onyx as an adjunct for spinal surgery is a feasible alternative. Larger prospective studies with matched controls are needed to make determinations of the efficacy of this intervention. This could translate into reduced intra-operative blood loss and improved surgical results. 
Bibliography

1. Bilsky $\mathrm{MH}$, Lis $\mathrm{E}$, Raizer J, Lee $\mathrm{H}$, Boland $\mathrm{P}$. The diagnosis and treatment of metastatic spinal tumor. The oncologist 1999;4:459-469.

2. Trubenbach J, Nagele T, Bauer T, Ernemann U. Preoperative embolization of cervical spine osteoblastomas: report of three cases. AJNR. American journal of neuroradiology 2006;27:1910-1912.

3. Rehak S, Krajina A, Ungermann L, Ryska P, Cerny V, Talab R, Kanta M, Bartos M. The role of embolization in radical surgery of renal cell carcinoma spinal metastases. Acta neurochirurgica 2008;150:1177-1181; discussion 1181.

4. Manke C, Bretschneider T, Lenhart M, Strotzer M, Neumann C, Gmeinwieser J, Feuerbach S. Spinal metastases from renal cell carcinoma: effect of preoperative particle embolization on intraoperative blood loss. AJNR. American journal of neuroradiology 2001;22:997-1003.

5. Olerud C, Jonsson H, Jr., Lofberg AM, Lorelius LE, Sjostrom L. Embolization of spinal metastases reduces peroperative blood loss. 21 patients operated on for renal cell carcinoma. Acta orthopaedica Scandinavica 1993;64:9-12.

6. O'Reilly GV, Kleefield J, Klein LA, Blume HW, Dubuisson D, Cosgrove GR. Embolization of solitary spinal metastases from renal cell carcinoma: alternative therapy for spinal cord or nerve root compression. Surgical neurology 1989;31:268-271.

7. Berkefeld J, Scale D, Kirchner J, Heinrich T, Kollath J. Hypervascular spinal tumors: influence of the embolization technique on perioperative hemorrhage. AJNR. American journal of neuroradiology 1999;20:757-763.

8. Shi HB, Suh DC, Lee HK, Lim SM, Kim DH, Choi CG, Lee CS, Rhim SC. Preoperative transarterial embolization of spinal tumor: embolization techniques and results. AJNR. American journal of neuroradiology 1999;20:2009-2015.

9. Smith TP, Gray L, Weinstein JN, Richardson WJ, Payne CS. Preoperative transarterial embolization of spinal column neoplasms. Journal of vascular and interventional radiology : JVIR 1995;6:863-869. 
10. Vetter SC, Strecker EP, Ackermann LW, Harms J. Preoperative embolization of cervical spine tumors. Cardiovascular and interventional radiology 1997;20:343-347.

11. Chalouhi N, Dumont AS, Tjoumakaris S, Gonzalez LF, Bilyk JR, Randazzo C, Hasan D, Dalyai RT, Rosenwasser $\mathrm{R}$, Jabbour $\mathrm{P}$. The superior ophthalmic vein approach for the treatment of carotidcavernous fistulas: a novel technique using Onyx. Neurosurg Focus 2012;32:E13.

12. Choi IS, Berenstein A. Surgical neuroangiography of the spine and spinal cord. Radiologic clinics of North America 1988;26:1131-1141.

13. Gore P, Theodore N, Brasiliense L, Kim LJ, Garrett M, Nakaji P, Gonzalez LF, McDougall CG, Albuquerque FC. The utility of onyx for preoperative embolization of cranial and spinal tumors. Neurosurgery 2008;62:1204-1211; discussion 1211-1202.

14. Kickuth R, Waldherr C, Hoppe H, Bonel HM, Ludwig K, Beck M, Triller J. Interventional management of hypervascular osseous metastasis: role of embolotherapy before orthopedic tumor resection and bone stabilization. AJR. American journal of roentgenology 2008;191:W240-247.

15. Prabhu VC, Bilsky MH, Jambhekar K, Panageas KS, Boland PJ, Lis E, Heier L, Nelson PK. Results of preoperative embolization for metastatic spinal neoplasms. Journal of neurosurgery 2003;98:156-164.

16. Deshmukh VR, Fiorella DJ, McDougall CG, Spetzler RF, Albuquerque FC. Preoperative embolization of central nervous system tumors. Neurosurgery clinics of North America 2005;16:411-432, xi.

17. Guzman R, Dubach-Schwizer S, Heini P, Lovblad KO, Kalbermatten D, Schroth G, Remonda L. Preoperative transarterial embolization of vertebral metastases. European spine journal : official publication of the European Spine Society, the European Spinal Deformity Society, and the European Section of the Cervical Spine Research Society 2005;14:263-268.

18. Kato S, Murakami H, Minami T, Demura S, Yoshioka K, Matsui O, Tsuchiya H. Preoperative embolization significantly decreases intraoperative blood loss during palliative surgery for spinal metastasis. Orthopedics 2012;35:e1389-1395.

19. Taniguchi T, Ohta K, Ohmura S, Yamamoto K, Kobayashi T. [Perioperative management for total en bloc spondylectomy--the effects of preoperative embolization and hypotensive anesthesia]. Masui. The Japanese journal of anesthesiology 2000;49:168-171.

20. Ashour R, Aziz-Sultan MA, Soltanolkotabi M, Schoeneman SE, Alden TD, Hurley MC, Dipatri AJ, Tomita T, Elhammady MS, Shaibani A. Safety and efficacy of onyx embolization for pediatric cranial and spinal vascular lesions and tumors. Neurosurgery 2012;71:773-784.

21. Elhammady MS, Peterson EC, Johnson JN, Aziz-Sultan MA. Preoperative onyx embolization of vascular head and neck tumors by direct puncture. World neurosurgery 2012;77:725-730.

22. Kobayashi K, Ozkan E, Tam A, Ensor J, Wallace MJ, Gupta S. Preoperative embolization of spinal tumors: variables affecting intraoperative blood loss after embolization. Acta Radiol 2012;53:935-942.

23. Robial N, Charles YP, Bogorin I, Godet J, Beaujeux R, Boujan F, Steib JP. Is preoperative embolization a prerequisite for spinal metastases surgical management? Orthopaedics \& traumatology, surgery \& research : OTSR 2012;98:536-542.

24. Elhammady MS, Wolfe SQ, Ashour R, Farhat H, Moftakhar R, Lieber BB, Aziz-Sultan MA. Safety and efficacy of vascular tumor embolization using Onyx: is angiographic devascularization sufficient? Journal of neurosurgery 2010;112:1039-1045.

Figure Legend 
Figure 1. 56 year-old male with a history of mid-back pain and ataxia. (a) MRI T1-weighted imaging of the thoracic spine, post-gadolinium, sagittal view, demonstrating an enhancing paraspinal mass with invasion into posterior elements of thoracic spine with spinal cord compression. (b) Digital Subtraction Angiography (DSA), selective T7 microcatheter injection demonstrating tumor blush. (c) DSA demonstrating decreased tumor filling after particle embolization. (d) MRI T1-weighted imaging, post-gadolinium, sagittal view, demonstrating no residual mass after staged embolization and surgical decompression and fusion.

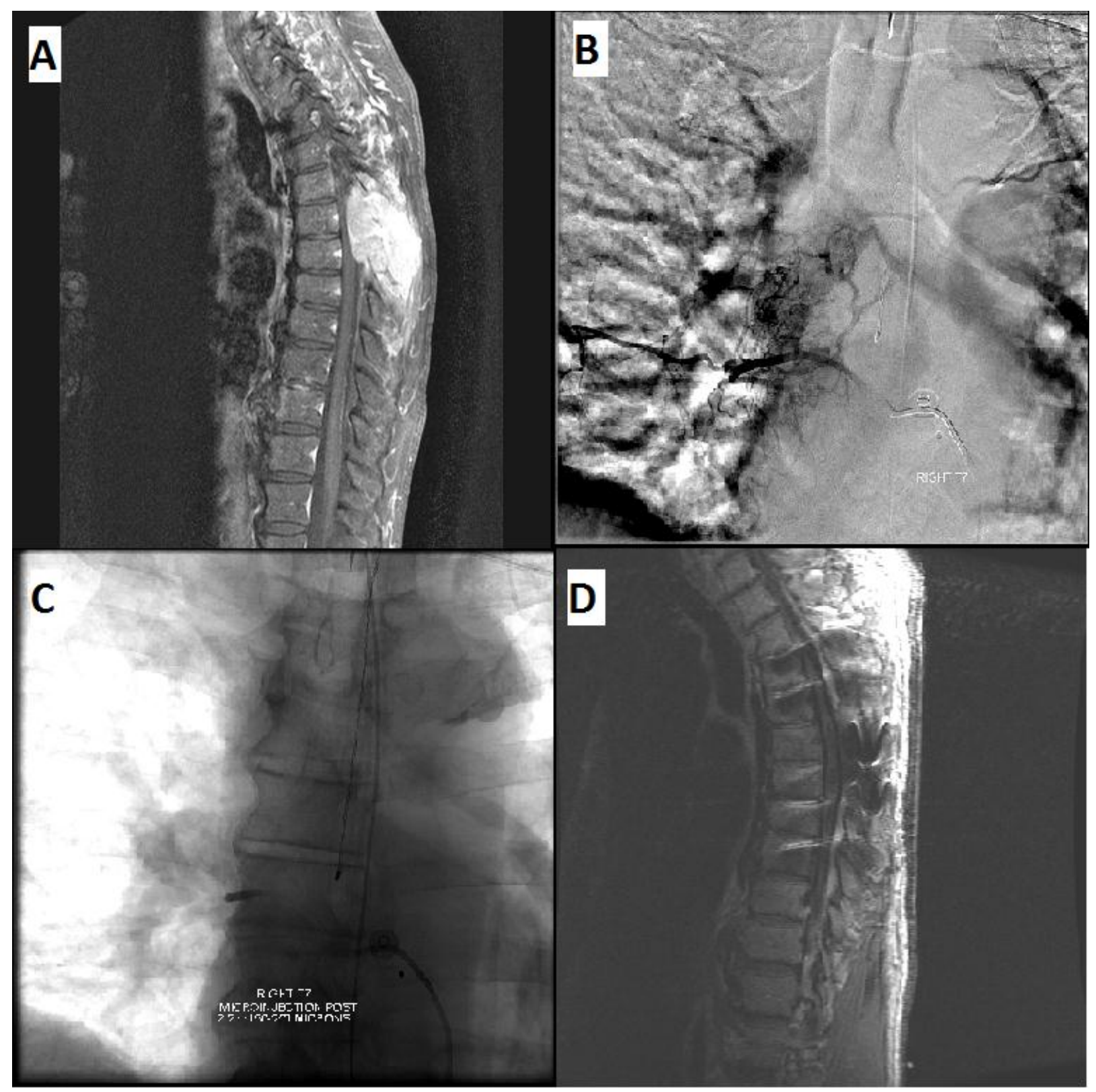


Table 1: Baseline Patient Characteristics

\begin{tabular}{|c|c|c|c|c|}
\hline Patient & Age & Gender & Metastasis & Cell type \\
\hline 1 & 53 & $\mathrm{~F}$ & $\mathrm{Y}$ & nasopharyngeal CA \\
\hline 2 & 59 & $\mathrm{~F}$ & $\mathrm{Y}$ & Carcinoma, indet. \\
\hline 3 & 60 & $\mathrm{~F}$ & $\mathrm{Y}$ & thyroid CA \\
\hline 4 & 57 & $\mathrm{~F}$ & $\mathrm{Y}$ & renal cell CA \\
\hline 5 & 49 & $\mathrm{~F}$ & $\mathrm{Y}$ & plasmacytoma \\
\hline 6 & 80 & $\mathrm{M}$ & $\mathrm{Y}$ & hemangioblastoma \\
\hline 7 & 41 & $\mathrm{M}$ & $\mathrm{Y}$ & renal cell CA \\
\hline 8 & 55 & $\mathrm{M}$ & $\mathrm{Y}$ & renal cell CA \\
\hline 9 & 71 & $\mathrm{M}$ & $\mathrm{Y}$ & renal cell CA \\
\hline 10 & 68 & $\mathrm{M}$ & $\mathrm{Y}$ & NSCLC \\
\hline 11 & 65 & $\mathrm{M}$ & $\mathrm{Y}$ & NSCLC \\
\hline 12 & 68 & $\mathrm{~F}$ & $\mathrm{Y}$ & renal cell CA \\
\hline 13 & 64 & $\mathrm{~F}$ & $\mathrm{Y}$ & thyroid CA \\
\hline 14 & 67 & $\mathrm{~F}$ & $\mathrm{Y}$ & renal cell CA \\
\hline 15 & 83 & $\mathrm{~F}$ & $\mathrm{Y}$ & renal cell CA \\
\hline 16 & 70 & M & $\mathrm{Y}$ & Carcinoma, indet. \\
\hline 17 & 48 & $\mathrm{~F}$ & $\mathrm{Y}$ & Carcinoma, indet. \\
\hline 18 & 58 & $\mathrm{~F}$ & $\mathrm{Y}$ & hemangiopericytoma \\
\hline 19 & 40 & $\mathrm{M}$ & $\mathrm{Y}$ & paraganglioma \\
\hline 20 & 66 & $\mathrm{~F}$ & $\mathrm{Y}$ & renal cell CA \\
\hline 21 & 52 & $\mathrm{~F}$ & $\mathrm{Y}$ & Carcinoma, indet. \\
\hline 22 & 71 & $\mathrm{~F}$ & $\mathrm{Y}$ & Carcinoma, indet. \\
\hline 23 & 42 & $\mathrm{M}$ & $\mathrm{Y}$ & renal cell CA \\
\hline 24 & 70 & $\mathrm{M}$ & $\mathrm{Y}$ & renal cell CA \\
\hline 25 & 54 & $\mathrm{M}$ & $\mathrm{Y}$ & renal cell CA \\
\hline 26 & 60 & $\mathrm{M}$ & $\mathrm{Y}$ & renal cell CA \\
\hline 27 & 64 & $\mathrm{M}$ & $\mathrm{Y}$ & renal cell CA \\
\hline 28 & 65 & $\mathrm{M}$ & $\mathrm{Y}$ & renal cell CA \\
\hline
\end{tabular}


Table 2. Spinal Embolization Procedural Characteristics

\begin{tabular}{|c|c|c|c|c|c|c|c|}
\hline Patient & Age & Gender & Pathology & Embolic agent & $\begin{array}{l}\text { Segments } \\
\text { embolized }\end{array}$ & Contrast(mL) & $\begin{array}{r}\text { Estimate } \\
\text { Obliteration }\end{array}$ \\
\hline 1 & 53 & $\mathrm{~F}$ & nasopharyngeal CA & NBCA & 2 & 100 & 100 \\
\hline 2 & 59 & $\mathrm{~F}$ & Carcinoma, indet. & onyx-18 & 1 & $\mathrm{n} / \mathrm{a}$ & $\mathrm{n} / \mathrm{a}$ \\
\hline 3 & 60 & $\mathrm{~F}$ & thyroid CA & onyx-34, onyx-18 & 2 & 250 & 100 \\
\hline 4 & 57 & $\mathrm{~F}$ & renal cell CA & onyx-18 & 1 & $\mathrm{n} / \mathrm{a}$ & 100 \\
\hline 5 & 49 & $\mathrm{~F}$ & plasmacytoma & onyx-18 & 1 & $\mathrm{n} / \mathrm{a}$ & 100 \\
\hline 6 & 80 & M & hemangioblastoma & onyx-34 & 1 & 250 & 95 \\
\hline 7 & 41 & $\mathrm{M}$ & renal cell CA & onyx-18 & 1 & 150 & 90 \\
\hline 8 & 55 & M & renal cell CA & onyx-18 & 1 & 100 & $\mathrm{n} / \mathrm{a}$ \\
\hline 9 & 71 & $\mathrm{M}$ & renal cell CA & onyx- 18 , coils & 2 & 200 & 95 \\
\hline 10 & 68 & $\mathrm{M}$ & NSCLC & onyx-18 & 1 & 100 & 100 \\
\hline 11 & 65 & $\mathrm{M}$ & NSCLC & NBCA & 1 & 140 & 100 \\
\hline 12 & 68 & $\mathrm{~F}$ & renal cell CA & onyx-18 & 3 & 120 & 100 \\
\hline 13 & 64 & $\mathrm{~F}$ & thyroid CA & onyx-18 & 4 & 200 & 90 \\
\hline 14 & 67 & $\mathrm{~F}$ & renal cell CA & Polyvinyl alcohol & 2 & 300 & 95 \\
\hline 15 & 83 & $\mathrm{~F}$ & renal cell CA & Polyvinyl alcohol & 1 & 190 & 100 \\
\hline 16 & 70 & M & Carcinoma, indet. & $\begin{array}{l}\text { Polyvinyl alcohol, } \\
\text { coils, embospheres }\end{array}$ & 2 & 210 & 75 \\
\hline 17 & 48 & $\mathrm{~F}$ & Carcinoma, indet. & Polyvinyl alcohol & 1 & 227 & 75 \\
\hline 18 & 58 & $\mathrm{~F}$ & hemangiopericytoma & $\begin{array}{l}\text { Polyvinyl alcohol, } \\
\text { coils, embospheres }\end{array}$ & 2 & 350 & 75 \\
\hline
\end{tabular}


Ghobrial 16

\begin{tabular}{|c|c|c|c|c|c|c|c|}
\hline 19 & 40 & M & paraganglioma & Polyvinyl alcohol & 4 & 147 & 100 \\
\hline 20 & 66 & $\mathrm{~F}$ & renal cell CA & embospheres & 2 & $\mathrm{n} / \mathrm{a}$ & 100 \\
\hline 21 & 52 & $\mathrm{~F}$ & Carcinoma, indet. & embospheres & 1 & $\mathrm{n} / \mathrm{a}$ & 100 \\
\hline 22 & 71 & $\mathrm{~F}$ & Carcinoma, indet. & embospheres & 2 & 210 & 95 \\
\hline 23 & 42 & $\mathrm{M}$ & renal cell CA & onyx-18 & 1 & $\mathrm{n} / \mathrm{a}$ & $\mathrm{n} / \mathrm{a}$ \\
\hline 24 & 70 & $\mathrm{M}$ & renal cell CA & onyx-18 & 2 & 110 & 100 \\
\hline 25 & 54 & $\mathrm{M}$ & renal cell CA & onyx-18 & 3 & 100 & 100 \\
\hline 26 & 60 & $\mathrm{M}$ & renal cell CA & Polyvinyl alcohol & 1 & 100 & 100 \\
\hline 27 & 64 & $\mathrm{M}$ & renal cell CA & onyx-18 & 2 & $\mathrm{n} / \mathrm{a}$ & $\mathrm{n} / \mathrm{a}$ \\
\hline 28 & 65 & $\mathrm{M}$ & renal cell CA & onyx-18 & 4 & 300 & 100 \\
\hline
\end{tabular}

Table 3A. Surgical Outcomes Summary

\begin{tabular}{|c|c|c|c|c|c|c|c|c|}
\hline $\begin{array}{c}\text { Patien } \\
\mathbf{t}\end{array}$ & Age & $\begin{array}{c}\text { Gende } \\
\mathbf{r} \\
\end{array}$ & Pathology & $\begin{array}{c}\text { LO } \\
\text { S } \\
\text { (d) }\end{array}$ & Complication & $\begin{array}{c}\text { EBL(cc } \\
)\end{array}$ & $\begin{array}{c}\text { PreO } \\
\text { p } \\
\text { mRS }\end{array}$ & $\begin{array}{l}\text { PostO } \\
\text { p mRS }\end{array}$ \\
\hline 1 & 53 & $\mathrm{~F}$ & nasopharyngeal CA & 7 & $\mathrm{~N}$ & $\mathrm{n} / \mathrm{a}$ & 4 & 4 \\
\hline 2 & 59 & $\mathrm{~F}$ & Carcinoma, indet. & 17 & $\begin{array}{l}\text { aortoiliac } \\
\text { thrombosis }\end{array}$ & $\mathrm{n} / \mathrm{a}$ & 2 & 2 \\
\hline 3 & 60 & $\mathrm{~F}$ & thyroid CA & 11 & $\mathrm{~N}$ & $\mathrm{n} / \mathrm{a}$ & 4 & 4 \\
\hline 4 & 57 & $\mathrm{~F}$ & renal cell CA & 50 & $\begin{array}{l}\text { Pulmonary } \\
\text { embolism }\end{array}$ & $\mathrm{n} / \mathrm{a}$ & 4 & 4 \\
\hline 5 & 49 & $\mathrm{~F}$ & plasmacytoma & 10 & $N$ & $\mathrm{n} / \mathrm{a}$ & 5 & 5 \\
\hline 6 & 80 & $\mathrm{M}$ & hemangioblastoma & 8 & $\mathrm{~N}$ & 350 & 5 & 5 \\
\hline 7 & 41 & M & renal cell CA & 7 & $\mathrm{~N}$ & $n / a$ & 4 & 4 \\
\hline
\end{tabular}


Ghobrial 17

\begin{tabular}{|c|c|c|c|c|c|c|c|c|}
\hline 8 & 55 & M & renal cell CA & 21 & $\mathrm{~N}$ & $\mathrm{n} / \mathrm{a}$ & 4 & 4 \\
\hline 9 & 71 & M & renal cell CA & 16 & $\mathrm{~N}$ & $\mathrm{n} / \mathrm{a}$ & 3 & 3 \\
\hline 10 & 68 & M & NSCLC & 28 & $\begin{array}{l}\text { Pulmonary } \\
\text { embolism }\end{array}$ & $\mathrm{n} / \mathrm{a}$ & 5 & 5 \\
\hline 11 & 65 & $\mathrm{M}$ & NSCLC & 55 & $\mathrm{~N}$ & $\mathrm{n} / \mathrm{a}$ & 3 & 3 \\
\hline 12 & 68 & $\mathrm{~F}$ & renal cell CA & 16 & $\mathrm{~N}$ & 1700 & 4 & 4 \\
\hline 13 & 64 & $\mathrm{~F}$ & thyroid CA & 23 & $\begin{array}{l}\text { Respiratory } \\
\text { Failure }\end{array}$ & $\mathrm{n} / \mathrm{a}$ & 2 & 2 \\
\hline 14 & 67 & $\mathrm{~F}$ & renal cell CA & 13 & iliac vein repair & 1000 & 4 & 4 \\
\hline 15 & 83 & $\mathrm{~F}$ & renal cell CA & 16 & $\begin{array}{c}\text { acute renal } \\
\text { failure, } \\
\text { urosepsis }\end{array}$ & 500 & 4 & 4 \\
\hline 16 & 70 & M & Carcinoma, indet. & 16 & $\begin{array}{c}\text { revision of } \\
\text { instrumentatio } \\
\mathrm{n}\end{array}$ & 1800 & 4 & 4 \\
\hline 17 & 48 & $\mathrm{~F}$ & Carcinoma, indet. & 13 & $\mathrm{~N}$ & 2000 & 3 & 2 \\
\hline 18 & 58 & $\mathrm{~F}$ & $\begin{array}{c}\text { hemangiopericytom } \\
\text { a }\end{array}$ & 34 & $\begin{array}{c}\text { Surgical site } \\
\text { infection }\end{array}$ & 3500 & 4 & 4 \\
\hline 19 & 40 & $\mathrm{M}$ & paraganglioma & 28 & $\mathrm{~N}$ & 1700 & 4 & 3 \\
\hline 20 & 66 & $\mathrm{~F}$ & renal cell CA & 8 & $\mathrm{~N}$ & 900 & 4 & 4 \\
\hline 21 & 52 & $\mathrm{~F}$ & Carcinoma, indet. & 5 & $\mathrm{~N}$ & 1000 & 1 & 1 \\
\hline 22 & 71 & $\mathrm{~F}$ & Carcinoma, indet. & 15 & $\begin{array}{l}\text { hardware } \\
\text { failure }\end{array}$ & 3700 & 3 & 3 \\
\hline 23 & 42 & M & renal cell CA & 23 & $\begin{array}{c}\text { Surgical site } \\
\text { infection }\end{array}$ & 700 & 4 & 4 \\
\hline 24 & 70 & M & renal cell CA & 8 & $\mathrm{~N}$ & 500 & 4 & 4 \\
\hline 25 & 54 & M & renal cell CA & 10 & wound & 450 & 1 & 1 \\
\hline
\end{tabular}




\begin{tabular}{|c|c|c|c|c|c|c|c|c|}
\hline & & & & infection & & & \\
\hline 26 & 60 & $\mathrm{M}$ & renal cell CA & 8 & $\mathrm{~N}$ & $\mathrm{n} / \mathrm{a}$ & 3 & 3 \\
\hline 27 & 64 & $\mathrm{M}$ & renal cell CA & 8 & $\mathrm{~N}$ & $\mathrm{n} / \mathrm{a}$ & 4 & 4 \\
\hline 28 & 65 & $\mathrm{M}$ & renal cell CA & 8 & $\mathrm{~N}$ & $\mathrm{n} / \mathrm{a}$ & 3 & 5 \\
\hline
\end{tabular}

Table 3b. Selected Surgical Details

\begin{tabular}{|c|c|c|c|c|c|c|c|}
\hline Patient & Age & Gender & Pathology & $\begin{array}{l}\text { LOS } \\
\text { (d) }\end{array}$ & $\begin{array}{c}\text { Spinal } \\
\text { decompression? }\end{array}$ & $\begin{array}{c}\text { Circumferential } \\
\text { (anterior/posterior)? }\end{array}$ & $\begin{array}{c}\text { Corpectomy } \\
\text { (partial, en- } \\
\text { bloc?) }\end{array}$ \\
\hline 1 & 53 & $\mathrm{~F}$ & nasopharyngeal CA & 7 & $\mathrm{~N}$ & yes & Partial \\
\hline 2 & 59 & $\mathrm{~F}$ & Carcinoma, indet. & 17 & $Y$ & yes & Partial \\
\hline 3 & 60 & $\mathrm{~F}$ & thyroid CA & 11 & $Y$ & yes & Partial \\
\hline 4 & 57 & $\mathrm{~F}$ & renal cell CA & 50 & $Y$ & $\mathrm{n} / \mathrm{a}$ & $\mathrm{n} / \mathrm{a}$ \\
\hline 5 & 49 & $\mathrm{~F}$ & plasmacytoma & 10 & $Y$ & no & $\mathrm{n} / \mathrm{a}$ \\
\hline 6 & 80 & M & hemangioblastoma & 8 & $Y$ & no & $\mathrm{n} / \mathrm{a}$ \\
\hline 7 & 41 & M & renal cell CA & 7 & $\mathrm{~N}$ & yes & Partial \\
\hline 8 & 55 & M & renal cell CA & 21 & $Y$ & yes & Partial \\
\hline 9 & 71 & M & renal cell CA & 16 & $Y$ & yes & Partial \\
\hline 10 & 68 & M & NSCLC & 28 & Y & yes & Partial \\
\hline 11 & 65 & M & NSCLC & 55 & $\mathrm{~N}$ & no & $\mathrm{n} / \mathrm{a}$ \\
\hline 12 & 68 & $\mathrm{~F}$ & renal cell CA & 16 & Y & no & $\begin{array}{c}\text { Partial, } \\
\text { lateral } \\
\text { extracavitary }\end{array}$ \\
\hline 13 & 64 & $\mathrm{~F}$ & thyroid CA & 23 & Y & no & $\begin{array}{c}\text { Partial, } \\
\text { lateral } \\
\text { extracavitary }\end{array}$ \\
\hline
\end{tabular}




\begin{tabular}{|c|c|c|c|c|c|c|c|}
\hline 14 & 67 & $\mathrm{~F}$ & renal cell CA & 13 & $Y$ & Yes & Partial \\
\hline 15 & 83 & $\mathrm{~F}$ & renal cell CA & 16 & $Y$ & No & $\mathrm{n} / \mathrm{a}$ \\
\hline 16 & 70 & M & Carcinoma, indet. & 16 & $Y$ & No & $b / a$ \\
\hline 17 & 48 & $\mathrm{~F}$ & Carcinoma, indet. & 13 & $Y$ & No & $\mathrm{n} / \mathrm{a}$ \\
\hline 18 & 58 & $\mathrm{~F}$ & hemangiopericytoma & 34 & Y & No & $\mathrm{n} / \mathrm{a}$ \\
\hline 19 & 40 & M & paraganglioma & 28 & $Y$ & Yes & Partial \\
\hline 20 & 66 & $\mathrm{~F}$ & renal cell CA & 8 & $Y$ & Yes & Partial \\
\hline 21 & 52 & $\mathrm{~F}$ & Carcinoma, indet. & 5 & $Y$ & Yes & Partial \\
\hline 22 & 71 & $\mathrm{~F}$ & Carcinoma, indet. & 15 & $Y$ & Yes & Partial \\
\hline 23 & 42 & M & renal cell CA & 23 & Y & No & $\mathrm{n} / \mathrm{a}$ \\
\hline 24 & 70 & M & renal cell CA & 8 & $Y$ & No & $\begin{array}{c}\text { Partial- } \\
\text { lateral } \\
\text { extracavitary }\end{array}$ \\
\hline 25 & 54 & $\mathrm{M}$ & renal cell CA & 10 & $Y$ & No & $\mathrm{n} / \mathrm{a}$ \\
\hline 26 & 60 & $\mathrm{M}$ & renal cell CA & 8 & $Y$ & No & $\mathrm{n} / \mathrm{a}$ \\
\hline 27 & 64 & M & renal cell CA & 8 & $\mathrm{~N}$ & No & $\mathrm{n} / \mathrm{a}$ \\
\hline 28 & 65 & $\mathrm{M}$ & renal cell CA & 8 & $Y$ & No & $\mathrm{n} / \mathrm{a}$ \\
\hline
\end{tabular}

Table 4. Onyx Embolization Characteristics

\begin{tabular}{|l|l|l|l|}
\hline $\begin{array}{l}\text { Embolization } \\
\text { Agent }\end{array}$ & Onyx & Other & p-value \\
\hline $\mathrm{N}$ & 16 & 12 & $\mathrm{P}>0.05$ \\
\hline $\begin{array}{l}\text { Median Decrease } \\
\text { in Tumor Blush }\end{array}$ & $97.8 \%$ & $92.7 \%$ & $\mathrm{P}=0.08$ \\
\hline $\begin{array}{l}\text { Median Surgical } \\
\text { EBL }\end{array}$ & 750 & 1844 & $\mathrm{P}=0.14$ \\
\hline
\end{tabular}




\begin{tabular}{|l|l|l|l|}
\hline Median LOS (d) & 17.4 & 15.9 & $\mathrm{P}=0.38$ \\
\hline $\begin{array}{l}\text { Median Pre- } \\
\text { operative mRS }\end{array}$ & 3.47 & 3.77 & $\mathrm{P}=0.36$ \\
\hline $\begin{array}{l}\text { Median Post- } \\
\text { operative mRS }\end{array}$ & 3.58 & 4.00 & $\mathrm{P}=0.09$ \\
\hline
\end{tabular}

Table 5: Previous selected series of presurgical embolization

\begin{tabular}{|c|c|c|c|c|c|c|c|c|c|c|}
\hline $\begin{array}{c}\text { Autho } \\
\text { rs }\end{array}$ & $\mathbf{N}$ & $\begin{array}{c}\text { mea } \\
\mathbf{n} \\
\text { age } \\
\end{array}$ & $\begin{array}{c}\text { Metast } \\
\text { atic? } \\
(\%)\end{array}$ & $\begin{array}{c}\text { Embolizat } \\
\text { ion } \\
\text { Method } \\
\end{array}$ & $\begin{array}{c}\text { cervi } \\
\text { cal( } \\
\%) \\
\end{array}$ & $\begin{array}{c}\text { thora } \\
\operatorname{cic}(\% \\
)\end{array}$ & $\begin{array}{c}\operatorname{lumb} \\
\operatorname{ar}(\% \\
)\end{array}$ & $\begin{array}{c}\text { Compl } \\
\text { ication } \\
? \\
\end{array}$ & $\begin{array}{c}\text { surger } \\
\mathbf{y}\end{array}$ & $\begin{array}{l}\text { EBL } \\
\text { (cc) }\end{array}$ \\
\hline $\begin{array}{l}\text { Shi et } \\
\text { al. }\end{array}$ & $\begin{array}{l}1 \\
8\end{array}$ & 42 & 16.7 & $\begin{array}{c}\text { Polyvinyl } \\
\text { Alcohol }\end{array}$ & 33 & 61 & 6 & 0 & $\begin{array}{c}\text { Decom } \\
\text { pressio } \\
\mathrm{n} \\
\text { fusion }\end{array}$ & 1100 \\
\hline $\begin{array}{l}\text { Berkef } \\
\text { eld et } \\
\text { al. }\end{array}$ & $\begin{array}{l}5 \\
9 \\
\end{array}$ & 54.2 & 78 & $\begin{array}{c}\text { particle/coi } \\
1\end{array}$ & 6 & 43 & 51 & $\begin{array}{c}1- \\
\text { transie } \\
\text { nt leg } \\
\text { weakne } \\
\text { ss }\end{array}$ & $\begin{array}{c}\text { corpect } \\
\text { omy }\end{array}$ & $\begin{array}{c}4350 \\
- \\
\text { contr } \\
\text { ol } \\
1850 \\
- \\
\text { partic } \\
\text { le/coil } \\
\text { s } \\
1800 \\
- \\
\text { partic } \\
\text { les } \\
\text { only }\end{array}$ \\
\hline $\begin{array}{l}\text { Wilson } \\
\text { et al. }\end{array}$ & $\begin{array}{l}1 \\
0 \\
0\end{array}$ & 54 & 71 & $\begin{array}{c}\text { Polyvinyl } \\
\text { Alcohol }\end{array}$ & 35 & 20 & 65 & $\begin{array}{l}1 \text {-acute } \\
\text { stroke }\end{array}$ & $\begin{array}{c}\text { ant } \\
\text { 13/post } \\
42 \\
\text { combin } \\
\text { ed } 45\end{array}$ & $\begin{array}{c}1562 \\
- \\
\text { prima } \\
\text { ry } \\
1652 \\
- \text { non- } \\
\text { RCC } \\
2856 \\
\text {-RCC }\end{array}$ \\
\hline $\begin{array}{c}\text { Gore et } \\
\text { al. }\end{array}$ & $\begin{array}{l}1 \\
0\end{array}$ & 33.5 & 40 & Onyx & 10 & 10 & 40 & 0 & $\begin{array}{c}\text { Decom } \\
\text { pressio } \\
n \\
\text { fusion }\end{array}$ & $\mathrm{n} / \mathrm{a}$ \\
\hline Vetter & 3 & 57 & 60 & PVA/coils/ & 100 & 0 & 0 & 0 & corpect & 2500 \\
\hline
\end{tabular}


Ghobrial 21

\begin{tabular}{|c|c|c|c|c|c|c|c|c|c|c|}
\hline et al. & 8 & & & gel foam & & & & & omy & \\
\hline $\begin{array}{l}\text { Nader } \\
\text { et al. }\end{array}$ & $\begin{array}{l}1 \\
0\end{array}$ & 58 & 50 & $\begin{array}{l}\text { PVA/coils/ } \\
\text { gel foam }\end{array}$ & 0 & 50 & 50 & $\begin{array}{c}1- \\
\text { parapar } \\
\text { esis }\end{array}$ & $\begin{array}{c}\text { corpect } \\
\text { omy }\end{array}$ & 2800 \\
\hline $\begin{array}{c}\text { Manke } \\
\text { et al. }\end{array}$ & $\begin{array}{l}1 \\
7\end{array}$ & 64 & 100 & $\begin{array}{c}\text { Polyvinyl } \\
\text { Alcohol }\end{array}$ & 18 & 54 & 27 & 0 & $\begin{array}{c}\text { corpect } \\
\text { omy }\end{array}$ & $\begin{array}{c}5000 \\
- \\
\text { contr } \\
\text { ol } \\
1500 \\
\text {-RCC }\end{array}$ \\
\hline
\end{tabular}

